Review Article

\title{
Earth Worms and Vermicomposting: A Review on the Story of Black Gold
}

\author{
Ali Ahmad ${ }^{1 *}$, Zubair Aslam ${ }^{1}$, Korkmaz Bellitürk $^{2}$, Naeem Iqbal $^{3}$, Muhammad Idrees $^{3}$, Muhammad Nawaz $^{4}$, \\ Muhammad Yasir Nawaz ${ }^{5}$, Muhammad Kashif Munir ${ }^{6}$, Ahmad Kamal ${ }^{1}$, Ehsan Ullah ${ }^{1}$, Muhammad Ahsan \\ Jamil $^{1}$, Yousuf Akram ${ }^{1}$, Tanveer Abbas ${ }^{1}$ and Muhammad Mohsin Aziz ${ }^{1}$
}

${ }^{1}$ Department of Agronomy, University of Agriculture Faisalabad, 38000, Pakistan; ${ }^{2}$ Department of Soil Science and Plant Nutrition, Faculty of Agriculture, Tekirdag Namık Kemal University, Suleymanpasa Tekirdag, Turkey; ${ }^{3}$ Plant Physiology Section, Agronomic Research Institute, AARI, Faisalabad, Pakistan; ${ }^{4}$ Vegetable and Oil Seed Section, Agronomic Research Institute, AARI, Faisalabad, Pakistan; 'Department of Pathology, Faculty of Veterinary Science, University of Agriculture Faisalabad, 38000, Pakistan; ${ }^{6}$ Cereals and Pulses Section, Agronomic Research Institute, AARI, Faisalabad, Pakistan.

Abstract | Presenting the world state of the art review, which summarizes the core ideas from experiments
performed by expert researchers on vermicomposting. Vermicompost is a finely decomposed peat like material
having good aeration, high drainage, good water holding capacity, microbial activity, superior in nutrient status
and buffering capacity therefore having the amiable required physiochemical charms for fertility of soil and
growth of plant. The worms increase the biological decomposition of organic substrates by maintaining the
aerobic conditions of the organic substrates. Experiments on earthworms and the vermicast production by
different species are also included in review. The paper also reveals fitness or compatibility of different species
of earthworms to 'bioprocess' variation in different forms of organic waste. The review also presents the basic
idea of all those research studies about effect of vermicomposting on different parameters of plant growth.
Such an explanatory review is remarkably few and far among studies about the impact on plants of vermicasts
prepared from aquatic weeds and agriculture wastes.
Received $\mid$ April 09, 2021; Accepted | April 29,2021; Published | June 07, 2021
*Correspondence | Ali Ahmad, Department of Agronomy, University of Agriculture Faisalabad, 38000, Pakistan; Email: aliahmadsial2643@
gmail.com
Citation | Ahmad, A., Z. Aslam, K. Bellitürk, N. Iqbal, M. Idrees, M. Nawaz, M.Y. Nawaz, M.K. Munir, A. Kamal, E. Ullah, M.A. Jamil, Y.
Akram, T. Abbas and M.M. Aziz. 2021. Earth worms and vermicomposting: A review on the story of black gold. Journal of Innovative Sciences,
7(1): 167-173.
DOI $\mid$ https://dx.doi.org/10.17582/journal.jis/2021/7.1.167.173
Keywords | Enzymes, Growth promoters and regulators, Macro and micro nutrients, Hormones, Vermicast

\section{Introduction}

$\mathrm{V}$ ermicomposting is a term coined to explain the whole process of utilization of biodegradable material by earthworms and producing vermicasts. The process enhances the bioavailability of basic nutrients by consuming raw nutrients and reproducing useful byproducts. Vermicast is also reported for having descend of growth sufficient hormones i.e. ethylene, auxin, gibberellin and enzymes i.e. cellulose, nitrogenase, phosphatase etc. Those nutrients are produced during the passage of degradable mass through the gut of earthworm. It is also a strong belief that all such hormones and enzymes are plant growth stimulants while inhibit the pathogen invasion causing different diseases. The environmental friendly and pure organic highly nutritious fertilizer vermicompost fertilizer is used for crop production 
and soil management (Celik et al., 2020). Overall, the vermicast is recommended for its organic fertilizing ability along with soil conditioning. The most recent experiments reported by concerned researchers (Aslam et al., 2020; Aslam and Ahmad, 2020; Belliturk et al., 2020) revealed the potential of vermicomposting for beneficial effects on plants. In this review paper, the authors are presenting a brief but comprehensive review of vermicomposting and special features of the process involving all frontline players responsible for nutrient enrichment by earthworms.

\subsection{Earthworm}

Earthworms (Table 1) taxonomically classify into phylum annelida and are long, cylindrical, narrow, segmented and symmetrically bilateral soil inhabiting invertebrates having a glittering brownish body encased with smooth cuticular layer. The weight of earthworms range to $1400-1500 \mathrm{mg}$ after $1 / 2$ month and are reproductively hermaphrodite. The body of earthworm comprises protein (65\%), carbohydrates and fat (14\%) and 3\% ash. The life cycle of earthworm differs within 3-7 years relying on the ecological conditions. The earthworm gut is linear tube initiate from mouth part accompanied by pharyngeal, esophagus, slender walled crop, gizzard, digestive glands and ultimately terminate with anal cavity. Mucus found in gut of earthworm including amino acids, minerals, organic matter, polysaccharide and protein as well symbiotic microbes namely (microfungi, protozoa and bacteria). Enhancement in total organic $\mathrm{C}: \mathrm{N}$ and moisture content of earthworm gut generate suitable condition for germination of bacterial endospore and activation of dormant microorganisms. Amylase, protease, cellolase, chitinase, protease, lipase and urease like digestive enzymes have been reported from the food canal of earthworm. It was found that mannose and cellulose were being carried out through the gut of microbes (Munnoli et al., 2010). Earthworms break down the raw material and thus increase the surface area of microbial degrading substrates that starts the active vermicomposting stage. As the organic matter carry through the intestine, it is mixed with microbes associated with intestine and digestive enzymes and finally in partially digested form as "casts" removes from the intestine after which the process of degradation starts by microbes, which parrticipates to the maturation period (Aslam et al., 2020; Ahmad et al., 2021).

Earthworms and microflora interaction is very complex and therefore earthworms digested the various groups of microorganisms as dietary source. These microbes contain protozoa, few yeasts and certain species of fungus as Fusarium oxysporum, Alternaria solani, Drawida calebi. Bacillus cereus var mycoides were digested by the species of earthworm Lumbricus terrestris and Eisenia foetida whereas Serratia marcessens and Escherichia coli are not included in passage through intestine of earthworm (Aslam et al., 2020; Ahmad et al., 2021).

\subsection{Characteristics of Eisenia fetida}

Eisenia fetida (Savigny, 1926) belongs to the phylum Annelida and family lumbericidae (Pavlíček and Csuzdi, 2012). These worms are red, purple, or brown in colour, with a yellowish belly. Its segment number ranges from 80 to 110, with lengths ranging from 23 to $130 \mathrm{~mm}$. Among segments 24, 25, 26, or 32, the genital belt extends to 7-9 pieces during puberty. The weight of the adult worm is about $1.5 \mathrm{~g}$ and they can reproduce about 50 to 55 days when they come out of the cocoon. Adult worms will produce a cocoon every three days on average, with one third of newborns coming out of the cocoon after 23 days. Although all infants do not survive (Belliturk et al., 2020).

Esienia fetida (Figure 1) is a type of surface-born waste-born and fertilizer-maker, and its inhabitants are mass manure, horticultural land with large quantities of organic material, forest and areas with a lot of wood and leaves waste, and it can serve as a suitable degrading in soil. It can live in a wide range of environment types and is active in all seasons. The intake and reproduction rate of food in these worms is high and they are rich in organic matter and have life, nutrition and reproduction potential in environments so that these worms use the daily equivalent of half their weight of organic waste (Tohidinejad et al., 2011).

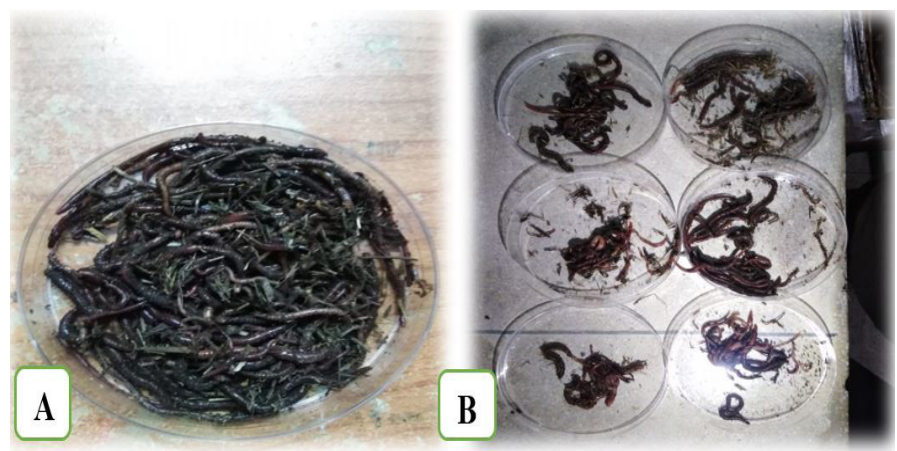

Figure 1: Eisenia Fetida in (A) Rice straw,(B) Wheat straw. 


\subsection{Vermicomposting}

Vermicomposting (Figure 2) is viable and eco-friendly technology which is mainly integrated to convert waste organic residue into useful organic rich humus under aerobic condition. Vermicomposting noticeably involve in degradation and stabilization of solid organic waste frictions into fine organic rich manure derived from vermicompost processing can be efficiently reserved, handled and integrated to agricultural lands without any negative impacts (Aslam et al., 2020). Vermicomposting is an integrated interaction of earthworms and mesophilic microorganisms in ecofriendly environment and stabilized conditions in order to attain non-thermophilic degradation and stabilization of solid organic waste frictions. (Aslam and Ahmad, 2020). Production of vermicompost by the action of earthworms generally include macromicro nutrients, growth regulating hormones, growth promoters and regulators, plant immobilized microflora, cellular components degrading enzymes (lipase, chitinase, amylases, proteases and cellulose) (Figure 5) and these enzymes further degrade the organic substrates even they are secreted from earthworms (Rehman et al., 2020). These growth promoters, regulators, i.e. (Figure 5 and 6)proline, glycine betaine, ascorbic acid, salicylic acid (Ahmad et al., 2019) etc. nutrients i.e. nitrogen, potassium, phosphorus, calcium, magnesium, iron etc. are helpful to plants survive under drought stress conditions (Ahmad et al., 2019; Ali et al., 2018). Earthworms modify the physical and chemical status of organic substrates, slowly alleviating the $\mathrm{C}: \mathrm{N}$ ratio of organic matter, enhancing the surface area exposed to microbes and creating it more promising for microbial action for further degradation. The organic matter, structure, texture, $\mathrm{pH}$, is improved by vermicompost addition. It also maintain various positive environmental factors like soil temperature and moisture (Kilbacak et al., 2021). The movement of fine organic frictions and bacteria- excrements in the gut of earthworm therefore will lead to the homogenization of organic substrates. The final product of vermicompost is a fine fractionalized humus like organic material having high water-retaining capacity and porosity that includes essential nutrients and minerals such as ammonium and nitrate which are easily accessible to plants (Aslam et al., 2020).

\subsection{Vermicomposting procedure and process}

The following (Figure 3 and 4) illustrate the vermcomposting procedure and process;

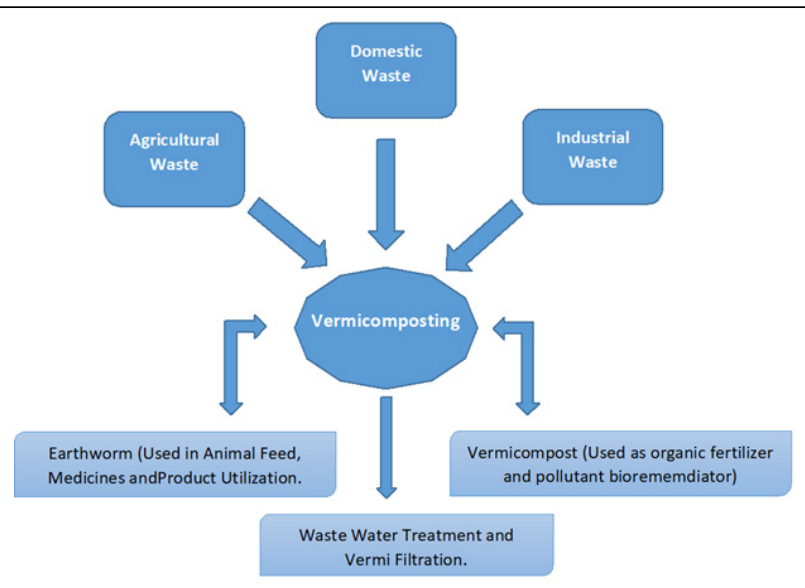

Figure 2: Vermi-technology.
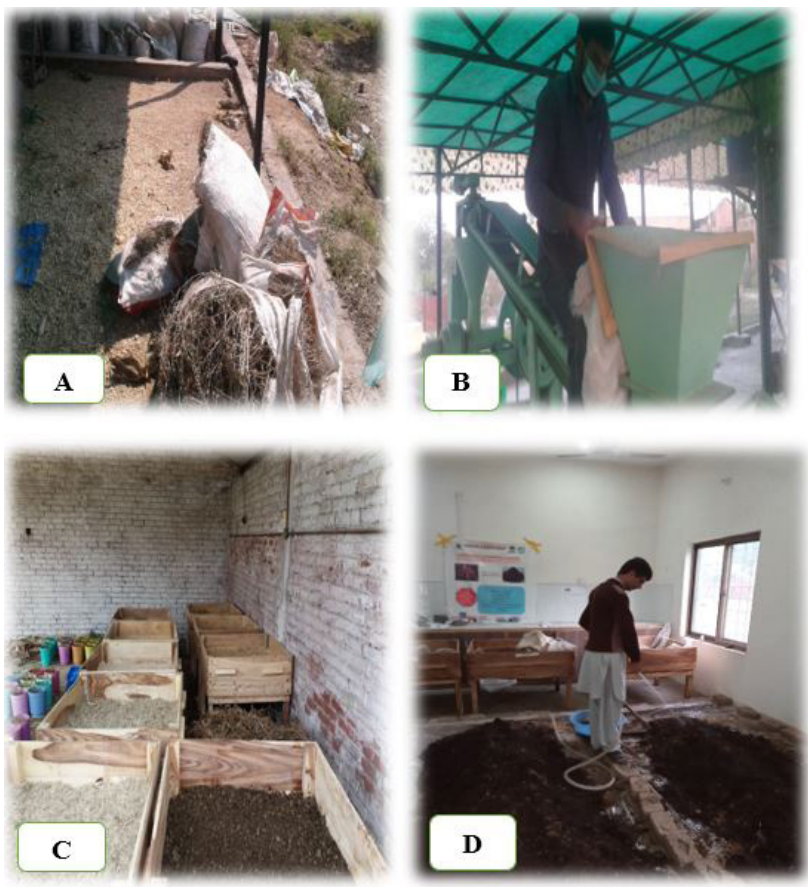

Figure 3: Vermicomposting procedures (A) Collection of Materials, (B) Crushing of materials, (C) Pre-composting, (D) Watering.

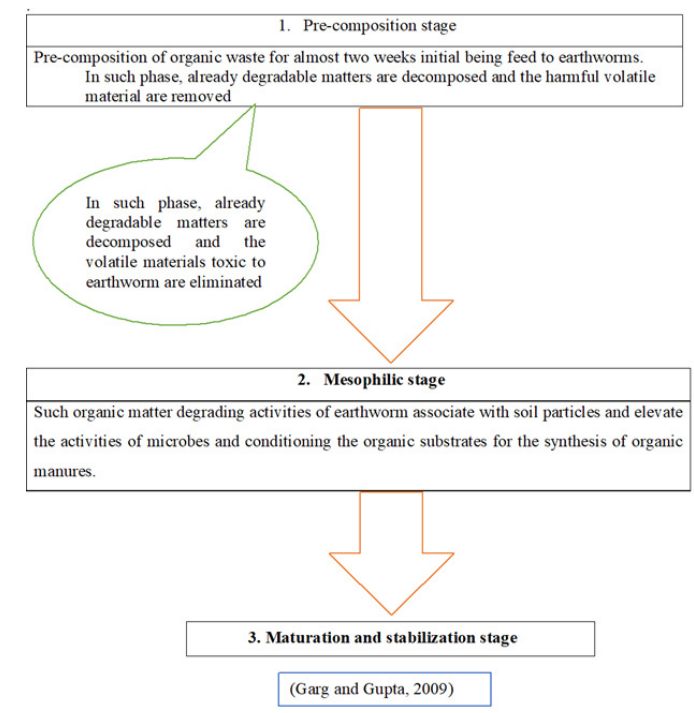

Figure 4: Illustrate the vermcomposting process. 
Table 1: Earth worm's ecological classification, ecological interaction, characteristics and advantageous features.

\begin{tabular}{|c|c|c|c|c|}
\hline Earthworm species & $\begin{array}{l}\text { Ecological } \\
\text { classification }\end{array}$ & $\begin{array}{l}\text { Ecological } \\
\text { Interaction }\end{array}$ & Characteristics & $\begin{array}{l}\text { Advantageous } \\
\text { features }\end{array}$ \\
\hline $\begin{array}{l}\text { D. octaedra, Bimastus } \\
\text { minusculus, Dendrobaena } \\
\text { veneta, Dendrodrilus rubidus, B. } \\
\text { eiseni, Lumbricus spps } \\
\text { Eiseniella tetraedra and Eisenia } \\
\text { foetida }\end{array}$ & $\begin{array}{l}\text { Epigeic spe- } \\
\text { cies }\end{array}$ & $\begin{array}{l}\text { found in super- } \\
\text { ficial soil layers, } \\
\text { compost and leaf } \\
\text { litter }\end{array}$ & $\begin{array}{l}\text { Smaller in size, body uniformly } \\
\text { pigmented, active gizzard, short } \\
\text { life cycle, high reproduction rate } \\
\text { and regeneration, tolerant to } \\
\text { disturbance, phytophagous }\end{array}$ & $\begin{array}{l}\text { Effective compost } \\
\text { producers, assists in } \\
\text { litter } \\
\text { pulverization and } \\
\text { early decomposition, } \\
\text { efficient bio- } \\
\text { degraders and } \\
\text { nutrient releasers }\end{array}$ \\
\hline $\begin{array}{l}\text { Aporrectodea. rosea, } A \text {. caliginosa } \\
\text { A. trapezoids and } \\
\text { Millsonia anomala }\end{array}$ & $\begin{array}{l}\text { Endogeic } \\
\text { Species }\end{array}$ & $\begin{array}{l}\text { Dwell in upper } \\
\text { soil and sub-soil }\end{array}$ & $\begin{array}{l}\text { Large to small in size, less pigment- } \\
\text { ed body, geophagous, life cycle of } \\
\text { medium period, fairly } \\
\text { tolerant to disturbance }\end{array}$ & \\
\hline $\begin{array}{l}\text { Octolasion lacteum and } O . \\
\text { cyaneum }\end{array}$ & $\begin{array}{l}\text { Endogeic and } \\
\text { Polyhumic } \\
\text { species }\end{array}$ & $\begin{array}{l}\text { Upper soil, type } \\
\text { (A1) }\end{array}$ & $\begin{array}{l}\text { Non-pigmented body, small in size, } \\
\text { rich soil feeder, burrowing horizon- } \\
\text { tally in soil }\end{array}$ & \\
\hline $\begin{array}{l}\text { Allolobophora chlorotica and } \\
\text { Pontoscolex corethrurus, }\end{array}$ & $\begin{array}{l}\text { Endogeic and } \\
\text { Mesohumic } \\
\text { Species }\end{array}$ & $\begin{array}{l}\text { (A and B hori- } \\
\text { zon) soil layers }\end{array}$ & $\begin{array}{l}\text { Non-pigmented body, medium in } \\
\text { size, create intensive horizontal } \\
\text { burrows in soil, feed on bulk soil } \\
\left(A_{1}\right) \text { - type }\end{array}$ & \\
\hline Aminthas sp & $\begin{array}{l}\text { Endogeic and } \\
\text { Oligohumic } \\
\text { Species }\end{array}$ & $\begin{array}{l}\text { (B and } \mathrm{C} \text { hori- } \\
\text { zon) soil layers }\end{array}$ & $\begin{array}{l}\text { Very large in size, unpigmented, } \\
\text { forms intensive horizontal } \\
\text { burrows, feeds on poor, deep soils }\end{array}$ & \\
\hline $\begin{array}{l}\text { A. longa, L. Polyphemus and } L \text {. } \\
\text { terrestris, }\end{array}$ & Anecic species & $\begin{array}{l}\text { Extensively } \\
\text { burrow in soil }\end{array}$ & $\begin{array}{l}\text { Pigmented at dorsal portion of the } \\
\text { body, larger in size, less reproduc- } \\
\text { tion rate, nocturnal, phytogeoph- } \\
\text { agous extensively form vertically } \\
\text { deep permanent burrowing holes } \\
\text { in soil }\end{array}$ & $\begin{array}{l}\text { Involve in blending } \\
\text { of soil nutrients }\end{array}$ \\
\hline
\end{tabular}

(Kooch and Jalilvand, 2008; Pathma and Sakthivel, 2012).

Table 2: Reveals the nutrients concentration found in vermicompost.

\begin{tabular}{ll}
\hline Nutrients & Quantity \\
\hline $\mathrm{S}$ & 128.0 to $548.0 \mathrm{mg} \mathrm{kg}^{-1}$ \\
$\mathrm{Zn}$ & 5.7 to $9.3 \mathrm{mg} \mathrm{kg}^{-1}$ \\
$\mathrm{Fe}$ & 2.0 to $9.3 \mathrm{mg} \mathrm{kg}^{-1}$ \\
$\mathrm{Cu}$ & 2.0 to $9.3 \mathrm{mg} \mathrm{kg}^{-1}$ \\
$\mathrm{Ca}$ and $\mathrm{Mg}$ & 22.67 to $47.6(\mathrm{Meq} / 100 \mathrm{~g})$ \\
$\mathrm{Na}$ & 0.055 to $0.3 \%$ \\
$\mathrm{P}$ & 0.1 to $0.26 \%$ \\
$\mathrm{~K}$ & 0.15 to $0.256 \%$ \\
$\mathrm{~N}$ & 0.5 to $0.9 \%$ \\
$\mathrm{C}$ & 9.15 to $17.88 \%$ \\
\hline
\end{tabular}

Garg and Gupta, 2009.

\subsection{Chemical composition of vermicompost}

Vermicompost is a mulch related organic matter including utmost minerals and nutrients which are already available to plant such as $\mathrm{Ca}, \mathrm{K}, \mathrm{PO}_{4}{ }^{2-}$ and $\mathrm{NO}_{3}^{-1}$ ions etc. This organic manure has great water holding capacity (WHC), porosity and large surface exposure area, which is responsible for providing adequate sites for microbial functionality as well for retaining of essential nutrients. The production of plant growth regulating hormones for instance, cytokinins, auxins and other mulch materials are achieved from microbial activities are found in vermicomposts. (Table 2 and 3).

\section{Conclusions and Recommendations}

It can be concluded from this study that vermicompost is the process of conversion of waste in to black gold that contains digestive enzymes such as amylase, cellulase, protease, lipase, chitinase and urease, macro and micro nutrients i.e. nitrogen $(\mathrm{N})$, phosphorus $(\mathrm{P})$, potassium $(\mathrm{K})$, iron $(\mathrm{Fe})$, zinc $(\mathrm{Zn})$, sulphur $(\mathrm{S})$, growth promoters and regulators i.e. ascorbic acid, salicylic acid, proline, glycine betaine etc. that are helpful for plants to survive under stress conditions that may be drought, salinity, high temperature, chilling, pests and diseases. 
Table 3: Effect of vermicompost on agronomic traits of cereal crop.

\begin{tabular}{|c|c|c|c|c|}
\hline Cereal crop & Nutrient sources & Plant attributes & Country & \\
\hline Wheat & $\begin{array}{l}\text { Vermicompost integrated with } \\
\text { organic or inorganic fertilizers }\end{array}$ & $\begin{array}{l}\text { Improvement in growth, reproductive, soil } \\
\text { nutrient, physio-chemical and yield traits }\end{array}$ & Pakistan & Aslam et al., 2019 \\
\hline
\end{tabular}
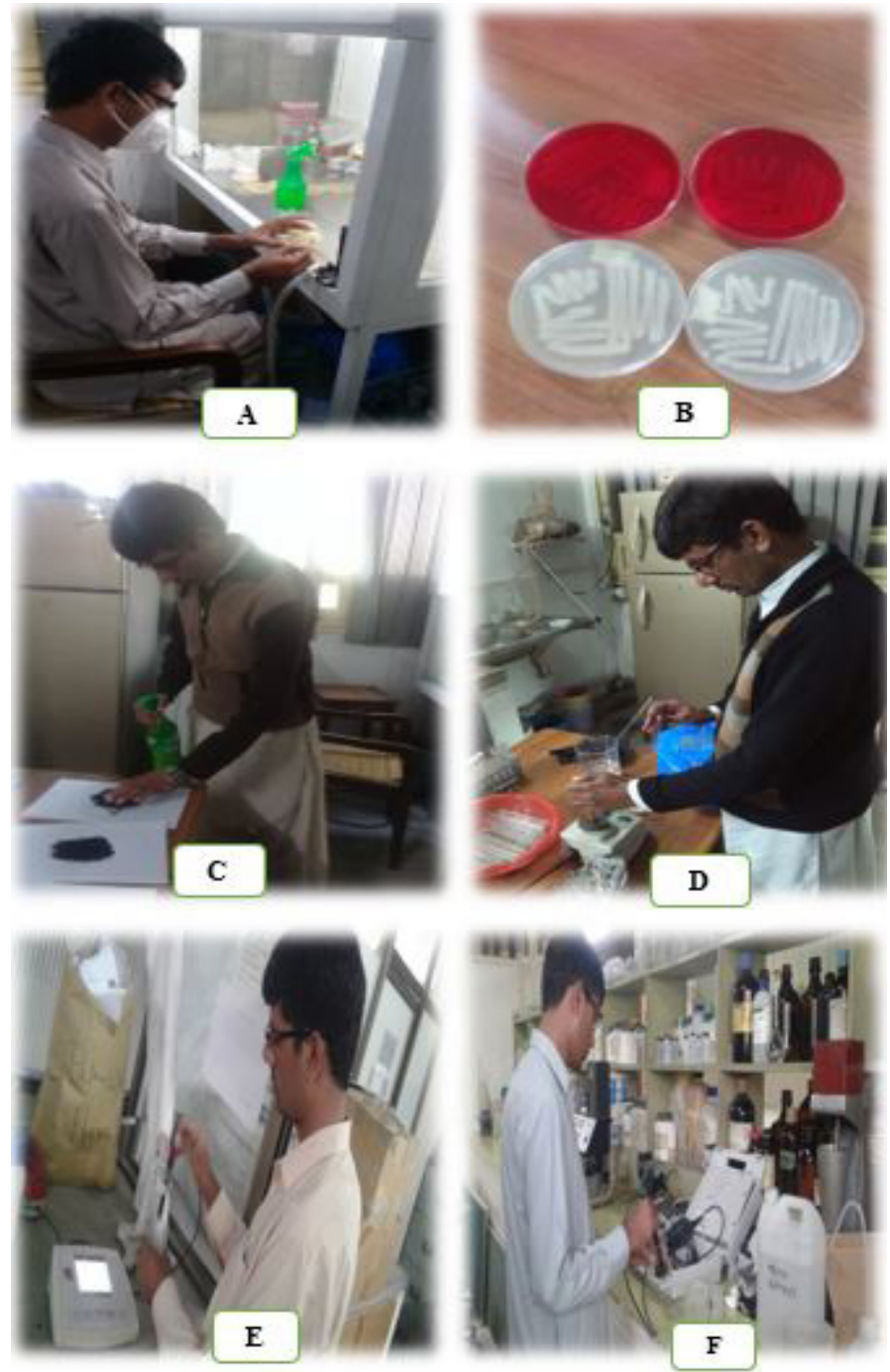

Figure 5: Vermicompost Chemical analysis, (A) Streaking of bacteria's, (B) Cellulose degrading bacerias collected from earth worm's gut, (C) Inoculation of bacteria in vermicompost, (D) Dilution of vermicompost in water, $(\mathrm{E}) \mathrm{pH}$ measurement, $(\mathrm{F})$ Ec. Measurement.

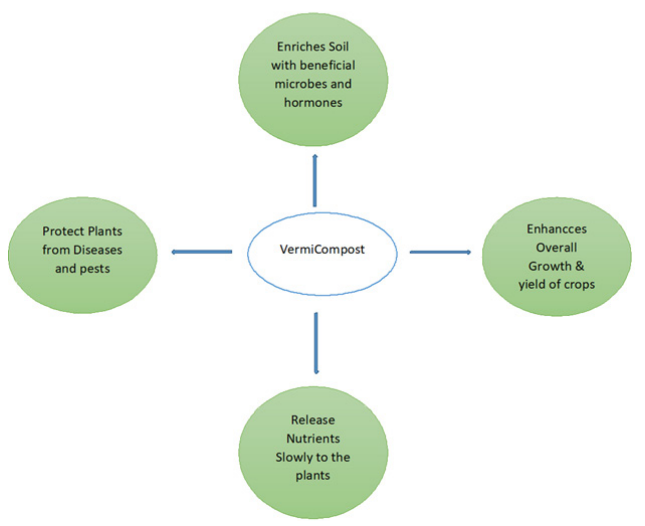

Figure 6: Vermicomposting benefits.

\section{Acknowledgements}

The authors gratefully acknowledge HEC for providing financial support to carry out this research work under HEC projects ["NRPU-HEC project no. 7527/Punjab/NRPU/R\&D/HEC/2017_Vermicomposting: A resourceful organic fertilizer to improve agriculture production and soil health and Second project "Vermicomposting: An Agricultural Waste Management Technology”, Pak-Turk Researchers Mobility Grant Program Phase- II, vide letter No. (Ph- II-MG-9)/ PAKTURK/ R\&D/HEC/2018”].

\section{Novelty Statement}

Vermicompost is complete and readily available nutrition for all crops. When vermicompost fully prepared then earthworms are used for feed of poultry and fisheries. No research work had done in Pakistan on this topic. Dr. Zubair Aslam, Associate Professor, Department of Agronomy, Faculty of Agriculture, University of Agriculture, Faisalabad, introduce this technology first in 2019. Now a days chemicals are deteriorating our environment and causing stresses in plants animals and humans. This organic way of nutrition for plants, birds and fisheries would be helpful for healthy lives. This technology is environment friendly, economically viable and socially acceptable for plant, fisheries and birds nutrition.

\section{Author's Contribution}

AA, ZA, KB, MKM, NI, MI, MN, MYN, YA, TA, MAJ, AK, EU and MMA: Conceived and designed the experiment, performed the experiment, analyzed the data, contributed reagents/ materials/ analysis tools, wrote the paper.

Conflict of interests

The authors have declared no conflict of interest.

\section{References}

Ahmad, A., Aslam, Z., Bellitürk, K., Iqbal, N., Naeem, S., Idrees, M., Kaleem,Z., Nawaz, M.Y., 
Nawaz,M., Sajjad,M., Rehman, M.U., Ramzan, H.N. Waqas, M., Akram, Y., Jamal, M.A., Ibrahim, M.U., Baig, H.A.T. and Kamal, A., 2021. Vermicomposting methods from different wastes: an environment friendly, economically viable and socially acceptable approach for crop nutrition: A review. International Journal of Food Science and Agriculture, 5(1): 58-68. https://doi. org/10.26855/ijfsa.2021.03.009

Ahmad, A., Aslam, Z., Ilyas, M.Z., Ameer, H., Mehmood, A. and Rehan, M., 2019. Drought stress mitigation by foliar feeding of potassium and amino acids in wheat. Journal of Environmental and Agricultural Sciences, 18: 10-18.

Ahmad, A., Aslam, Z., Iqbal, N., Idrees, M., Bellitürk, K., Rehman, S.U., Ameer, H., Ibrahim, M.U., Samiullah and Rehan, M., 2019. Effect of exogenous application of osmolytes on growth and yield of wheat under drought conditions. Journal of Environmental and Agricultural Sciences, 21: 6-13.

Ahmad, A., Ilyas, M.Z., Aslam, Z., Roman, M., Ali, A., Naeem, S., Nazar, M. and Rehman, S.U., 2019. Physiological screening of cotton (Gossypium birsutum L.) genotypes against drought tolerance. Pure Applied Biology, 9(1): 140-147. https://doi.org/10.19045/ bspab.2020.90017

Ali, A., Ahmad, A., Rashid, M., Kalhoro, S.A., Maqbool, M., Ahmed, M., Marri, F.A. and Khan, K.M., 2018. Screening of maize (Zea mays L.) hybrids based on drought tolerance under hydroponic conditions. Pure and Applied Biology, 7(4): 625-633.

Aslam, Z. and Ahmad, A., 2020. Effects of vermicompost, vermi-tea and chemical fertilizer on morpho-physiological characteristics of maize (Zea mays L.) in Suleymanpasa District, Tekirdag of Turkey. Journal of Innovative Sciences, 6(1): 41-46. https://doi.org/10.17582/ journal.jis/2020/6.1.41.46

Aslam, Z., Bashir, S., Hassan, W., Bellitürk, K., Ahmad, N., Niazi, N.K. and Maitah, M., 2019. Unveiling the efficiency of vermicompost derived from different biowastes on wheat (Triticum aestivum L.) plant growth and soil health. Agronomy, 9(12): 791. https://doi. org/10.3390/agronomy9120791

Aslam, Z., Ahmad, A., Bellitürk, K., Iqbal, N., Idrees, M., Rehman, W.U., Akbar, G., Tariq,
M., Raza, M., Riasat, S. and Rehman, S.U., 2020. Effects of vermicompost, vermi-tea and chemical fertilizer on morpho-physiological characteristics of tomato (Solanum lycopersicum) in Suleymanpasa District, Tekirdag of Turkey. Pure and Applied Biology 9(3): 1920-1931. https://doi.org/10.19045/bspab.2020.90205

Aslam, Z., Ahmad, A., Idrees, I., Iqbal, I., Akbar, G., Ali, U., Ibrahim, M.U., Bellitürk, K., Naeem, S., Nawaz, M., Nadeem, M., Waqas, M., Rehman, W.R., Sajjad, M., Samiullah and Akram, Y., 2020. Comparative analysis of nutritional sources on the morphophysiological characteristics of mung bean (Vigna radiata). International Journal of Food Science and Agriculture, 4(3): 314-322. https:// doi.org/10.26855/ijfsa.2020.09.011

Bellitürk, K., Aslam, Z., Ahmad, A. and Rehman, S.U., 2020. Alteration of physical and chemical properties of livestock manures by Eisenia fetida (Savigny, 1926) and developing valuable organic fertilizer. Journal of Innovative Sciences, 6(1): 47-53. https://doi.org/10.17582/journal. jis/2020/6.1.47.53

Celik, A., Belliturk, K. and Sakin, E., 2020. Agriculture friendly bio fertilizers in waste management: vermicompost and biochar. New approaches and applications in agriculture. (Editor: Mehmet Firat Baran). Iksad Publications 2020@ ISBN: 978-625-7279-666.

Garg, V.K. and Gupta, R., 2009. Vermicomposting of agro-industrial processing waste. In: Biotechnology for Agro-Industrial Residues Utilisation. Springer, Dordrecht, pp. 431-456. https://doi.org/10.1007/978-1-4020-99427 24

Hussain, S., Sharif, M., Khan, S., Wahid, F., Nihar, H., Ahmad, W. and Yaseen, T., 2016. Vermicompost and mycorrhiza effect on yield and phosphorus uptake of wheat crop. Sarbad Journal of Agriculture, 32(4). https://doi. org/10.17582/journal.sja/2016.32.4.372.381

Kilbacak, H., Belliturk, K. and Çelik, A., 2021. From vegetable and animal wastes producing vermicompost: green almond shell and sheep fertilizer mixture example. Overview of Agriculture the Academic Perspective. (Editor: Gulsah Bengisu). Iksad Publications -2021(C) ISBN: 978-605-70345-3-3, pp. 19-44.

Kooch, Y. and Jalilvand, H., 2008. Earthworm as 
ecosystem engineers and the most important detritions in frost soils. Pakistan Journal of Biological Sciences, 11: 819-825. https://doi. org/10.3923/pjbs.2008.819.825

Munnoli, P.M., Da Silva, J.A.T. and Saroj, B. 2010. Dynamics of the soil-earthwormplant relationship: A review. Dynamic Soil and Dynamic Plant p (Special Issue II on vermitechnology-2010). pp. 1-21. Pathma, J. and Sakthivel, N., 2012. Microbial diversity of vermicompost bacteria that exhibit useful agricultural traits and waste management potential. Springer Plus, 1(1): 1-19. https://doi. org/10.1186/2193-1801-1-26

Pavlíček, T. and Csuzdi, C., 2012. Earthworm fauna of French Guiana. Zoology in the Middle East, 58(sup4): 107-110. https://doi.org/10.1080/09 397140.2012.10648991

Rehman, S.U., Aslam, Z., Bellitürk, K., Ahmad, A., Nadeem, M. and Waqas, M., 2020. Vermicomposting in Pakistan: Current Scenario and Future Prospectives. Modern Concepts and Development in Agronomy, 6(1): 617-619. https://doi.org/10.31031/ MCDA.2020.06.000629

Tohidinejad, E., Madani, H. and Jenabi, M., 2011. Organic fertilizers and vermicompost. Shabid Bahonar University of Kerman Publications. pp. 150. 